those who have to cope with malnutrition problems and indicates sources of protein for dietary improvement as well as production methods which might be suitable for particular local conditions. Product distribution is considered to be a very important part of any scheme of this nature. Prospects in the market for bananas, and costings for orange squash production have been subjects for reports. The natural products chemical research division reports on three of its current projects. The fungus growing on mouldy corn has been found to cause disease in pigs and cattle that eat it, and the toxins produced by Penicillium rubrum are thought to be the cause. The mycotoxins section of the institute has been working on these toxins and has found, in experiments with mice, that damage is caused to the liver. Work on the chemistry of scirpentriol and verrucarol is also described, the interest being in reactions leading to detoxication. Diacetoxyscirpenol has been implicated in the important problem of mouldy corn toxicosis. There has also been a search for reasonably simple, naturally occurring antifungal molecules which are obtainable by synthesis, but results have proved disappointing so far. Investigation is still going on into more complex molecules.

The services of the Tropical Products Institute are available to almost any country and enquiries were received from eighty-eight different countries during 1966. The work of the institute is growing, as seen in the budget figures for the last two years. For 1966-67 it was $£ 360,000$ and for the current year, 1967-68, $£ 444,000$.

\section{Finding Bombs}

In August a panel of experts met at the International Atomic Energy Headquarters in Vienna to discuss techniques of ensuring that atomic installations are not used for military purposes. The members of the panel came from Canada, India and Japan as well as the four nuclear powers which are members of the agency. In addition, there were observers from West Germany, Czechoslovakia, the European Nuclear Energy Agency and Euratom. The British member of the panel was Dr Frank Morgan of AWRE Aldermaston; Mr D. B. B. Janisch of UKAEA Risley and Mr J. McAdam Clark of the Ministry of Technology were present as observers.

The panel discussed how to verify statements on the movement of fuels, and the production of plutonium and electricity by a reactor. Methods of non-destructive analysis of nuclear fuel, and of sealing techniques, were also considered. The panel concluded its work by recommending the directions the agency's research into safeguards techniques should take.

\section{Immigrating Animals}

Trre most unusual immigrant granted right of entry to Britain in 1966 may well have been the rhinoceros bred in a West German Zoo. Other rare wild animals for which import licences have been granted are listed in a report published by the Advisory Committee on the Animals (Restriction of Importation) Act, 1964 (HMSO, 3s.). This report is the first of an annual summary of statistics of animal importation and gives numbers of licences granted in 1965 and 1966.
The Advisory Committee concentrates on conservation of wild animals and advises both the Board of Trade, which grants the licences, and the Customs, who enforce them. The animal families are classified by rarity into two groups, rare and not so rare. During 1966, 22 Anthropoid Apes (Pongidae) were refused admission. Conservationists will also be pleased to learn that in 1966 as compared to 1965 , a larger number of licences was granted to only two of the 17 families mentioned. These two were opossums and marmosets. The highest figure is, surprisingly, not for Old World Monkeys (Cercopithecidae, 21,066) but for tortoises (Testudinidae). Despite a fall of 16,446 from the previous year it still stood at 320,573 . The committee says that the life span of this animal must be severely reduced when it comes into Britain. As yet it does not know what effect this trade is having on the animal in its wild state in any particular area.

The rest of the report covers countries of origin of the animals and declared purpose of importationthe latter is divided into the four categories of exhibition, scientific research, pets and resale. The rhinoceros was heading for exhibition, but one of the 16 opossums was named as a pet. Despite the appearance of the wombat in the list of the rare animals, it seems that nobody has attempted to import one in the past two years. The statistics refer to the number of licences issued, not to the number of animals brought in. They are therefore in some way misleading, for not all the licences were taken up. During last year, however, the Board of Trade changed the system so that 1967 will be the first year in which the number of animals arriving will be accurately known.

\section{New Man at Argonne}

IT has been announced that Dr R. B. Duffield is to become the Director of the Argonne National Laboratory of the United States Atomic Energy Commission. He will take up his appointment in November. Immediately after receiving his doctor's degree from the University of California at Berkeley, in 1943, Dr Duffield became a member of the team of workers on the Manhattan Project at Los Alamos Laboratory. In 1946, he joined the staff of the University of Illinois where he worked for ten years, finally becoming associate professor. He then became chairman of the chemistry department of the General Atomic Division of the General Dynamics Corporation, where he directed first the design and later the operation of the high temperature gas cooled reactor at Peach Bottom, Pennsylvania. His work in connexion with this brought him on many visits to the Dragon Project at Winfrith which collaborates with the Peach Bottom team. Dr Duffield will be the first chemist, as opposed to a physicist, to direct Argonne, and there may be significance in the fact that his recent experience has been concerned with reactor research; his predecessor, Dr A. V. Crewe, returned to the University of Chicago to continue basic research.

\section{Exporting Science}

In spite of the trouble in Nigeria and the devaluation of the Indian rupee, the British Council remains 